\title{
Pengaruh Pemberian Ekstrak Etanol Daun Kemangi Sayur (Ocimum Basilicum) Terhadap Kadar Serum Alanin Aminotrasferase (ALT) dan Aspartat Aminotrasferase (AST) Mencit (Mus musculus) Jantan Galur Swiss yang Diinjeksi Asam Urat
}

\author{
Abdul Khalik Adam ${ }^{1}$, Anis Kusumawati ${ }^{1}$, Rizka Adi Nugraha Putra ${ }^{1}$ \\ ${ }^{I}$ Fakultas Kedokteran, Universitas Muhammadiyah Purwokerto
}

\begin{abstract}
ABSTRAK
Latar Belakang: ALT dan AST merupakan suatu biomarker yang dapat mengindikasikan adanya kerusakan hepatosit. Hiperurisemia diketahui merupakan salah satu penyebab utama cedera hepatosit sehingga hiperurisemia yang tidak terkontrol akan menyebabkan kerusakan pada hepar. Ocimum basilicum (kemangi sayur) diketahui memiliki kandungan antioksidan tinggi dan sifat hepatoprotektif sehingga berpotensi untuk menjadi terapi herbal alternatif pencegahan kerusakan hepar akibat hiperurisemia.

Tujuan: Mengetahui pengaruh pemberian ekstrak daun kemangi terhadap kadar serum ALT dan AST pada mencit (Mus musculus) yang diinjeksi asam urat. Penelitian ini merupakan quasy experimental dengan post-test only control group design. Penelitian ini menggunakan 25 ekor mencit yang diinjeksi asam urat intraperitoneal sebanyak $125 \mathrm{mg} / \mathrm{KgBB}$, kemudian dilakukan pemberian terapi ekstrak etanol daun kemangi sayur dengan dosis $11,2 \mathrm{mg} / 20 \mathrm{gBB}, 14 \mathrm{mg} / 20 \mathrm{gBB}$, dan $16,8 \mathrm{mg} / 20 \mathrm{gBB}$. Data kadar AST dilakukan pengujian statistik menggunakan uji ANOVA dan Post-Hoc Bonferroni test, sedangkan data kadar ALT menggunakan uji Kruskal Wallis dan Mann-Whitney test.

Hasil: Terdapat perbedaan rerata yang bermakna pada kadar AST serum $(p=0,00)$

maupun pada kadar ALT serum $(p=0,008)$ secara keseluruhan kelompok. Perbedaan kadar AST serum tampak signifikan pada kelompok $\mathrm{K}+$ terhadap $\mathrm{K} 1(p=0,039), \mathrm{K}+$ terhadap $\mathrm{K} 2(p=0,001)$, dan $\mathrm{K}+$ terhadap $\mathrm{K} 3(p=0,008)$. Sedangkan pada kadar ALT serum, adanya perbedaan yang bermakna didapatkan pada kelompok K+ terhadap K1 $(p=0,047), \mathrm{K}+$ terhadap $\mathrm{K} 2(p=0,009)$, dan $\mathrm{K}+$ terhadap $\mathrm{K} 3(p=0,009)$.

Simpulan: Pemberian ekstrak etanol daun kemangi sayur memiliki pengaruh terhadap penurunan kadar AST dan ALT serum pada mencit yang diinjeksi asam urat.

Kata Kunci: Hiperurisemia, AST, ALT, Ocimum basilicum, antioksidan
\end{abstract}

\section{ABSTRACT}

Background: ALT and AST are biomarkers which can indicate the existence of damaged hepatocytes. Hyperuricemia is known as a main cause of hepatocyte injury so that uncontrolled hyperuricemia will create damage on liver. Ocimum basilicum (basil) is known to have high antioxidant content and hepatoprotective character thus it is potential to be an alternative of herbal therapy to prevent damaged liver caused by hyperuricemia.

Objectives: To discover the effect of basil leaf extract on the level of ALT and AST serum of mice (Mus musculus) injected with uric acid.

Methods: This was a quasi-experimental research with post-test only control group design. Twenty five mice were used and injected with $125 \mathrm{mg} / \mathrm{kgwt}$ of intraperitoneal uric acid. Then they were treated with ethanolic leaf extracts of basil with various dose; $11.2 \mathrm{mg} / 20 \mathrm{gwt}, 14 \mathrm{mg} / 20 \mathrm{gwt}$, and $16.8 \mathrm{mg} / 20 \mathrm{gwt}$. The data of ALT level was tested statistically using ANOVA and Post-Hoc Bonferroni test, while that of AST level was tested using Kruskal Wallis and Mann-Whitney test.

Result: There was significant difference of mean on the level of ALT $(p=0.00)$ and AST serum $(p=0.008)$ in whole groups. Difference level of ALT serum occurred significantly on group K+ toward K1 ( $p=0.039), \mathrm{K}+$ toward $\mathrm{K} 2(\mathrm{p}=0.001)$, and $\mathrm{K}+$ toward $\mathrm{K} 3(\mathrm{p}=0.008)$. While on serum AST level, presence significant differences obtained on group $\mathrm{K}+$ toward $\mathrm{K} 1(\mathrm{p}=0.047), \mathrm{K}+$ toward $\mathrm{K} 2(\mathrm{p}=0.009)$, and $\mathrm{K}+$ toward $\mathrm{K} 3(\mathrm{p}=$ 0.009).

Conclusion: The ethanolic leaf extracts of basil had effects on the decrease of the level of ALT and AST serum of mice injected with uric acid.

Keywords: Hyperuricemia, ALT, AST, Ocimum basilicum, antioxidants 


\section{PENDAHULUAN}

Hepar merupakan organ yang sangat berperan dalam berbagai macam metabolisme penting didalam tubuh manusia yang disusun oleh sel-sel yang di sebut dengan hepatosit. Hepatosit mempunyai peran utama dalam metabolisme yang terjadi dihepar, sehingga cedera pada hepatosit akan menyebabkan peningkatan suatu enzim dalam serum yang spesifik sebagai indikator kerusakan hepar. Terdapat dua macam enzim yang terdapat dalam serum dan selalu dihubungkan dengan cedera hepatosit yaitu Aspartat aminotransferase (AST) dan Alanin aminotransferase $(\mathrm{ALT})^{1}$

Cedera pada hepatosit dapat disebabkan oleh keadaan infeksi maupun noninfeksi, salah satu penyebab noninfeksi pada cedera hepatosit adalah suatu peningkatan kadar asam urat atau biasa disebut dengan keadaan hiperurisemia ${ }^{2}$. Keadaan hiperurisemia yang tidak terkontrol menyababkan cedera pada hepatosit yang merupakan tempat utama dalam metabolisme asam urat, sehingga akan menyebabkan terbentuknya jaringan parut pada struktur hepar ${ }^{3}$. Kejadian hiperurisemia di berbagai negara berdasarkan hasil survei dari National Health and Nutrition Examination Survei (NHANES) yang merupakan suatu lembaga survei kesehatan dan nutrisi di Amerika Serikat pada tahun 2007-2008 menyatakan terjadi peningkatan kejadian penderita hiperurisemia dari setiap tahunnya di Amerika Serikat. Sedangkan angka kejadian hiperusemia pada masyarakat Indonesia belum memiliki data yang pasti. Adanya penelitian mengenai kejadian hiperurisemia di desa Tenganan Pegrisingan Karangasem, Bali pada tahun 2011 didapatkan prevalensi kejadian hiperurisemia sebesar $28 \%$ dimana laki-laki $21 \%$ dan wanita $7 \%^{4}$. Dari data ini dapat di simpulkan bahwa masih terdapat angka kejadian hiperurisemia di tiap negara. Hal tersebut berpengaruh tingkat kesehatan dengan komplikasi penyakit pada berbagai organ tubuh manusia, terutama pada hepar ${ }^{5}$.

Hiperurisemia banyak di jumpai pada pada penduduk dunia, penyebab tersering hiperurisemia adalah peningkatan konsumsi makanan yang mengandung purin yang berasal dari pemecahan protein terutama jeroan, daging dan ikan ${ }^{6}$, yang pada umumnya banyak di konsumsi oleh masyarakat Indonesia.

Pembentukan asam urat berawal dari diet makanan yang mengandung tinggi purin serta adanya asam ribonukleat yang berasal dari sel- sel kemudian akan di ubah oleh enzim xantine oksidase menjadi hipoxantin, xantin dan asam urat .

Hiperurisemia juga dapat terjadi akibat penyakit peningkatan destruksi sel dari tubuh seperti psoriasis dan leukemia serta ketidak mampuan ginjal dalam mengekskresikan asam urat ${ }^{1}$. Sel hepatosit di 
hepar menjadi tempat utama metabolisme asam urat, jika terjadi kelainan metabolisme asam urat yang disebabkan oleh hiperurisemia maka akan mengakibatkan cedera pada hepatosit yang merupakan faktor risiko terjadinya fibrosis hepar ${ }^{8}$ Terapi farmakologis yang banyak digunakan di Indonesia untuk penatalaksanaan hiperurisemia adalah obat alopurinol, obat ini merupakan obat golongan Xanthineoxidase inhibitor, urokosurik dan urikolitik $^{9}$. Informatorium obat nasional Indonesia tahun 2008 menyebutkan bahwa alopurinol memiliki efek samping yaitu ruam pada kulit hingga pengelupasan kulit, gangguan saluran cerna, neuropati, vertigo, gangguan fungsi darah dan bersifat hepatotoksisitas ${ }^{10} \cdot$ Indonesia merupakan salah satu negara yang terdapat ribuan jenis tumbuhan yang diduga berkhasiat sebagai obat serta sering digunakan masyarakat secara turun temurun, tetapi kurangnya penelitian mengenai kandungan serta efektivitas dari suatu tumbuhan tersebut ${ }^{11}$. Daun kemangi sayur (Ocimum bacilicum) salah satu tumbuhan yang sering di konsumsi masyarakat Indonesia, dan diduga memiliki banyak fungsi dalam pengobatan berbagai macam penyakit. Dalam penelitian sebelumnya diketahui daun kemangi mempunyai kandungan antioksidan berupa eugenol, flavonoid dan asam ursalat yang berfungsi sebagi free radical scavanger dalam tubuh. Masyarakat Indonesia banyak mengkonsumsi jenis daun kemangi sayur (Ocimum bacilicum), yang sebelumnya telah diteliti kandungannya berupa flavonoid yang termaksud dalam antioksidan potensial dapat menghambat terbentuknya asam urat dengan aktivitasnya menghambat kerja enzim xanthine oksidase. Kandungan flavonoid dalam daun kemangi sayur berupa luteolin, quercetin, epigenin, dan kaemferol yang berpotensi sebagai penghambat pembentukan asam urat dan luteolin yang memiliki daya hambat terkuat diantara semua jenis flavonoid yang terkandung dalam kemangi sayur ${ }^{12}$. Penelitian ini didasarkan dari potensi terjadinya gangguan fungsi hepar karena keadaan hiperurisemia yang tidak terkontrol serta pengembangan terapi tumbuhan herbal yang sering di konsumsi masyarakat indonesia yaitu kemangi sayur (Ocimum basilicum). Daun kemangi mempunyai berbagai macam kandungan serta dapat mengatasi berbagai macam penyakit. Sehingga penelitian ini bertujuan untuk mengetahui efektivitas ekstrak etanol daun kemangi sayur (Ocimum basilicum) terhadap kadar ALT dan AST hepar mencit yang diinjeksi asam urat.

\section{BAHAN DAN METODE}

Bahan

Bahan yang digunakan dalam penelitian ini adalah ekstrak etanol daun kemangi, larutan etanol 90\%, asam urat (sigma aldrich), $\mathrm{NaOH} 0,1 \mathrm{M}$, reagen pemeriksaan kadar serum ALT dan AST, dan larutan $\mathrm{NaCl} 0,9 \%$.

\section{Metode}

Penelitian ini merupakan jenis penelitian 
quasy experimental dengan rancangan penelitian post test only controlled group design yang dilakukan selama 23 hari dari November-Desember 2017. Perlakuan hewan coba, pengukuran kadar serum ALT dan AST dilakukan di Laboratorium FK UMJ. Sebelum diberi perlakuan, hewan coba diaklimatisasi selama 14 hari. Kemudian dilakukan perlakuan selama 14 hari dengan dibagi menjadi 5 kelompok subjek dengan masing-masing terdiri dari 5 hewan coba yaitu kelompok kontrol negatif (K-), kontrol positif $(\mathrm{K}+)$, perlakuan $1(\mathrm{~K} 1)$, perlakuan $2(\mathrm{~K} 2)$, dan perlakuan 3 (K3). $\mathrm{K}+$ diberikan injeksi peritoneal asam urat yang telah di larutkan dalam $\mathrm{NaOH} 0,1 \mathrm{M}$ sebanyak 125 $\mathrm{mg} / \mathrm{kgBB} /$ hari tanpa perlakuan, sedangkan untuk Khanya diberikan injeksi $\mathrm{NaCl} \quad 0,9 \% \quad 0,2 \mathrm{ml}$ tanpa perlakuan. Sedangkan untuk K1, K2, dan K3 diberikan injeksi peritoneal asam urat sebanyak 125 $\mathrm{mg} / \mathrm{KgBB} /$ hari dengan pemberian ekstrak etanol daun kemangi sebanyak 11,2 mg/29gBB, $14 \mathrm{mg} / 20 \mathrm{gBB}$, dan $16,8 \mathrm{mg} / 20 \mathrm{gBB}$ secara berurutan setelah 2 jam paska injeksi asam urat. Pengukuran kadar ALT dan AST serum dilakukan di hari ke 15 untuk setiap sampel.

\section{Pengumpulan Sampel}

Sampel/hewan coba yang digunakan adalah mencit (Mus musculus) jantan galur swiss yang berusia 3-4 bulan dengan berat badan mencit rata-rata 30-40 gram. Jumlah hewan coba yang digunakan sebanyak 25 ekor, dengan masing-masing 5 ekor uuntuk setiap kelompok subjek penelitian.

\section{Analisis Statistik}

Analisis statistik dilakukan menggunakan perangkat lunak pengolah statistik. Data kadar ALT serum untuk setiap sampel dilakukan pengujian statistika menggunakan uji One Way ANOVA untuk mengetahui adanya perbedaan rerata yang bermakna pada keseluruhan kelompok. Selanjutnya dilakukan Uji Post-Hoc Bonferroni test untuk mengetahui kelompok- kelompok yang memiliki perbedaan rerata yang paling signifikan. Sedangkan data kadar AST serum dilakukan analisa statistika menggunakan uji Kruskal Wallis untuk mengetahui adanya perbedaan rerata yang bermakna pada keseluruhan kelompok. Selanjutnya dilakukan uji Mann-Whitney antar tiap kelompok penelitian untuk mengetahui kelompokkelompok yang memiliki perbedaan rerata yang paling signifikan. Nilai p-value $<0,05$ dianggap bermakna (tingkat kepercayaan 95\%).

\section{HASIL}

\section{Analisis pengaruh ekstrak etanol daun kemangi terhada kadar AST serum}

Analisis ini dilakukan menggunakan uji beda ANOVA untuk mengetahui adanya pengaruh pemberian ekstrak etanol daun kemangi terhadap kadar AST serum pada kelompok perlakuan (dengan dosis yang berbeda) dan kelompok kontrol. Hasil pengujian ANOVA didapatkan $p=0,00$ (pvalue $<0,05$ ) yang menunjukkan bahwa secara statistik terdapat 
perbedaan rerata yang signifikan pada kadar AST serum di tiap kelompok subjek penelitian. Hal ini juga tampak pada perbedaan rerata kadar AST serum pada tiap kelompok penelitian (Gambar 1).

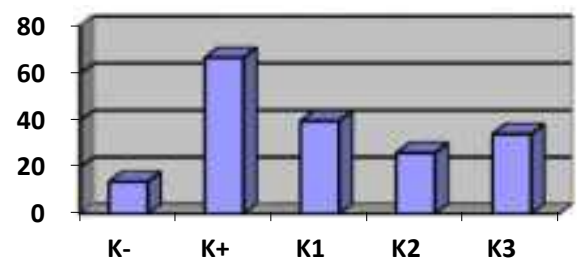

Gambar 1. Rerata kadar AST serum pada kelompok penelitian.

Gambar 1 menunjukkan bahwa pada kelompok perlakuan baik $\mathrm{K} 1$, K2, maupun $\mathrm{K} 3$ memiliki rerata kadar AST serum yang jauh lebih rendah dibandingkan pada kelompok $\mathrm{K}+$ (kontrol positif). Hal ini menunjukkan bahwa terdapat pengaruh pemberian ekstrak etanol daun kemangi terhadap penurunan kadar AST serum pada subjek penelitian. Setelah mendapatkan hasil pengujian ANOVA, selanjutnya dilakukan pengujian Post-Hoc Test untuk mengetahui perbedaan rerata kadar AST serum antar tiap kelompok sampel. Dari hasil pengujian didapatkan data bahwa tidak semua kelompok memiliki perbedaan rerata kadar AST serum terhadap kelompok lainnya.
Tabel 1. Hasil Post-Hoc Test menggunakan uji Bonferroni terhadap kadar AST serum pada tiap kelompok penelitian

\begin{tabular}{|c|c|c|}
\hline Kelompolsampel & $\begin{array}{c}\text { Kadar AST serum } \\
\text { Nansos. }\end{array}$ & 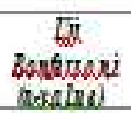 \\
\hline $\begin{array}{l}\mathrm{K}+(\mathrm{n}=\overline{5}) \\
\mathrm{K}-(\mathrm{n}=\overline{5})\end{array}$ & $\begin{array}{l}66,5=18.9 \\
13, ?=14,0\end{array}$ & $0.000^{*}$ \\
\hline $\begin{array}{l}\mathrm{K}+(\mathrm{n}=5) \\
\mathrm{K} 1 \mathrm{n}(\mathrm{n}=5)\end{array}$ & $\begin{array}{l}66,5=18,9 \\
30,6=9.1\end{array}$ & $0,039 *$ \\
\hline $\begin{array}{l}\mathrm{K}+(\mathrm{n}=5) \\
\mathrm{K} 2(\mathrm{n}=5)\end{array}$ & $\begin{array}{l}66,5=18,9 \\
25,9=13,8\end{array}$ & $0,001 * 1$ \\
\hline $\begin{array}{l}\mathrm{K}+(\mathrm{n}=5) \\
\mathrm{K} 3(\mathrm{n}=5)\end{array}$ & $\begin{array}{l}66,5=18,9 \\
34,0=4,5\end{array}$ & $0,008^{*}$ \\
\hline $\begin{array}{l}K-(n=5) \\
K L(n=5)\end{array}$ & $\begin{array}{l}13,2 \pm 14,0 \\
396-9 .\end{array}$ & 0,052 \\
\hline $\mathrm{K}-(\mathrm{D}=5)$ & $13,7=14,0$ & 1,000 \\
\hline $\mathrm{K} 2(\mathrm{n}-\mathbf{2})$ & $239 \cdot 138$ & \\
\hline $\mathrm{K}-(\mathrm{u}=5)$ & $137=14,0$ & 0,234 \\
\hline $\begin{array}{l}\mathrm{Kl}(\mathrm{n}=5) \\
\mathrm{K} /(\mathrm{a}-5)\end{array}$ & $\begin{array}{r}39.6 \pm 9.1 \\
25.9-13.8\end{array}$ & 1.000 \\
\hline $\mathrm{Kl}(\mathrm{n}=5)$ & $\begin{array}{l}39,6 \pm 9,1 \\
340=43\end{array}$ & 1,000 \\
\hline $\begin{array}{l}\mathrm{K} 2(\mathrm{u}=5) \\
\mathrm{K} 3(\mathrm{u}=5)\end{array}$ & $\begin{array}{r}25,=13,8 \\
34, Q=4,5\end{array}$ & 1,000 \\
\hline
\end{tabular}

Hasil penelitian ini menunjukkan bahwa ekstrak daun kemangi memiliki pengaruh dalam menurunkan kadar AST serum pada kelompok perlakuan pada setiap dosis ekstrak yang diberikan. Namun, hasil penelitian ini menunjukkan bahwa penurunan kadar AST serum tidak dipengaruhi oleh jumlah dosis ekstrak yang diberikan. Hal ini tampak pada kelompok perlakuan 3 (dosis 16,8 mg/20grBB ) memiliki penurunan rerata kadar AST serum yang lebih rendah dibandingkan kelompok perlakuan 2 (dosis $14 \mathrm{mg} / 20 \mathrm{grBB}$ ). Dari hasil penelitian ini juga menunjukkan bahwa dosis pemberian ektrak etanol daun kemangi yang menunjukkan penurunan kadar AST serum yang paling dramatis adalah pada pemberian dosis $14 \mathrm{mg} / 20 \mathrm{grBB}$. 


\section{Analisis pengaruh ekstrak etanol daun}

\section{kemangi terhadap kadar ALT serum}

Analisis ini dilakukan menggunakan uji nonparametrik Kruskal Wallis untuk mengetahui adanya pengaruh pemberian ekstrak etanol daun kemangi terhadap kadar ALT serum pada kelompok perlakuan (dengan dosis yang berbeda) dan kelompok kontrol. Hasil pengujian didapatkan $\mathrm{p}=0,008$ (pvalue $<0,05$ ) yang menunjukkan bahwa secara statistik terdapat perbedaan rerata yang signifikan pada kadar ALT serum dikeseluruhan kelompok subjek penelitian. Hal ini juga tampak pada perbedaan rerata kadar ALT serum pada tiap kelompok penelitian(Gambar2).

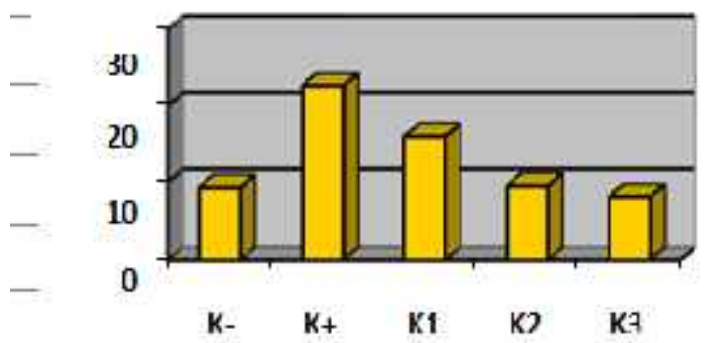

Gambar 2. Rerata kadar ALT serum pada Kelompok penelitian

Gambar 2 menunjukkan bahwa pada kelompok perlakuan baik K1, K2, maupun K3 memiliki rerata kadar ALT serum yang jauh lebih rendah dibandingkan pada kelompok $\mathrm{K}+$ (kontrol positif). Hal ini menunjukkan bahwa terdapat pengaruh pemberian ekstrak etanol daun kemangi terhadap penurunan kadar ALT serum pada subjek penelitian. Setelah mendapatkan hasil pengujian
Kruskal Wallis, dilakukan pengujian uji beda rerata menggunakan uji Mann-Whitney untuk mengetahui perbedaan rerata kadar ALT serum antar tiap kelompok sampel.

Tabel 2. Hasil uji Mann-Whitney terhadap kadar ALT serum pada tiap kelompok penelitian

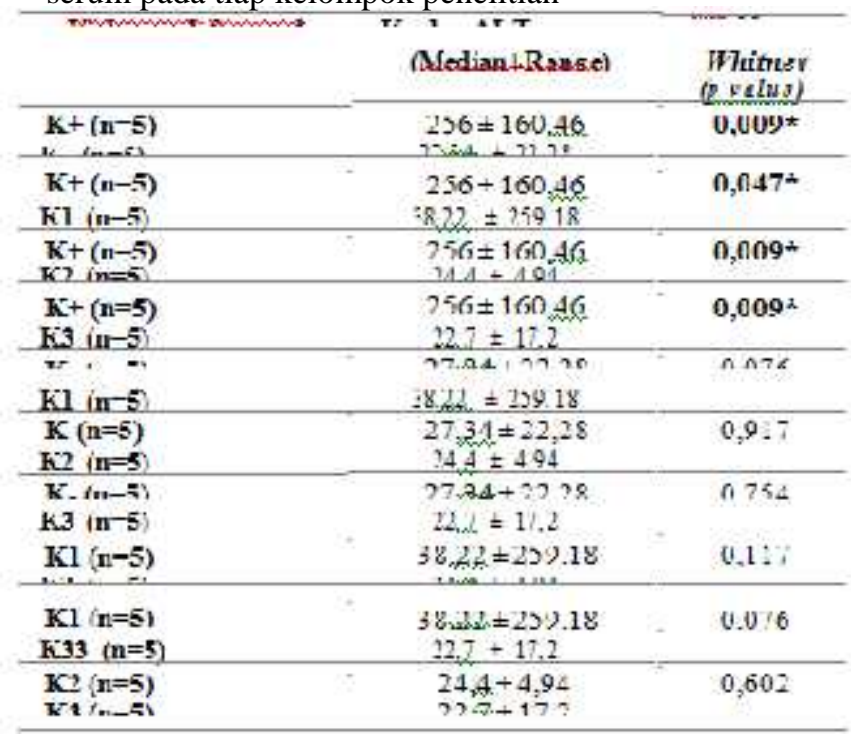

*menunjukkan signifikan pada tingkat kepercayaan 95\%.

Hasil penelitian ini menunjukkan bahwa ekstrak daun kemangi memiliki pengaruh dalam menurunkan kadar ALT serum pada kelompok perlakuan pada setiap dosis ekstrak yang diberikan. Hasil penelitian ini menunjukkan bahwa penurunan kadar ALT serum dapat dipengaruhi oleh jumlah dosis ekstrak yang diberikan. Hal ini tampak pada rerata kadar ALT serum yang semakin rendah saat diberikan peningkatan dosis esktrak kemangi. Dari hasil penelitian ini juga menunjukkan bahwa dosis pemberian ektrak etanol daun kemangi yang menunjukkan penurunan kadar ALT serum yang paling besar adalah pada pemberian dosis 16,8 $\mathrm{mg} / 20 \mathrm{grBB}$. 


\section{DISKUSI}

Penelitian ini menemukan bahwa terdapat perbedaan yang signifikan pada kadar AST dan ALT serum antara kelompok kontrol positif dan kontrol negatif dimana nilai rata-rata AST maupun ALT pada kelompok mencit yang diinduksi dengan asam urat secara signifikan lebih tinggi dibandingkan pada kelompok mencit tanpa induksi asam urat (kontrol negatif). Hasil ini menunjukkan bahwa induksi asam urat dapat menyebabkan peningkatan kadar AST dan ALT pada serum dimana merupakan marker yang mengindikasikan kerusakan pada hati.

Kerusakan hati dapat terdeteksi dengan mengukur aktivitas enzim fungsi hepar seperti AST, ALT, ALP, dan GGT, yang dilepaskan ke dalam darah dari sel hepatosit yang rusak ${ }^{16 .}$ Hasil ini sesuai dengan penelitian yang dilakukan oleh Lanaspa et al. (2002) menemukan hubungan yang kuat antara meningkatkan serum asam urat dengan penyakit NAFLD danfibrosis hati. Sejalan dengan hasil ini, studi yang dilakukan oleh Afzali (2010) juga melaporkan bahwa peningkatan serum asam untuk memiliki hubungan terhadap peningkatan penanda hepatic necroinflammation (ALT, AST dan GGT) dan risiko yang lebih tinggi untuk terjadinya sirosis hepar. Berdasarkan hasil penelitian terkait diatas dapat disimpulkan bahwa induksi asam urat memiliki potensi yang besar untuk menyebabkan kerusakan hepar yang ditandai dengan peningkatan kadar ALT dan AST pada serum.

Asam urat dapat menginduksi stres oksidatif pada sel vaskular, sel tubular, dan adiposit dengan adanya pembentukan radikal superoksida. Stres oksidatif diketahui merupakan faktor risiko utama terjadinya progresi penyakit hepar ${ }^{14}$. Studi yang dilakukan Sautin et al. (2007) menyebutkan bahwa asam urat dapat mencetuskan peningkatan produksi Reactive Oxygen Species (ROS) dan aktivitas NADPH oksidase (nicotinamide adenine dinucleotide phosphate-oxidase) pada sel. ROS merupakan suatu produk biomolekul seluler pada metabolisme organisme aerobik, yang timbul dari sumber endogen dan eksogen. ROS memiliki kemampuan memprovokasi respons imun, mengaktifkan onkogen, dan meningkatkan proses penuaan sel. Metabolisme.

ROS akan menghasilkan serangkaian molekul oksidan seperti superoksida dan spesies nitrogen reaktif lainnya ${ }^{16}$. Studi yang dilakukan Lanaspa et al. (2012) menunjukkan bahwa asam urat menstimulasi peningkatan metabolisme ROS dan aktivasi NADPH oksidase yang memproduksi radikal superoksida dan subunit NOX4. Molekulmolekul tersebut secara signifikan dapat menurunkan membran potensial mitokondria pada beberapa tipe sel termasuk sel hepatosit.

Studi ini juga menyebutkan bahwa pada kadar asam urat yang tinggi (750 umol/liter) 
menyebabkan perubahan pada morfologi mitokondria sel hepar dimana ditemukan mitokondria dengan bentuk yang lebih pendek dan kecil yang menandakan adanya fragmentasi mitokondria. Hasil penelitian ini membuktikan bahwa asam urat dapat menginduksi stres oksidatif pada mitokondria sel hepar melalui peran ROS dan NADPH oksidase. Stress oksidatif pada sel hepar menyebabkan kerusakan sel hepatosit sehingga terjadi peningkatan kadar ALT dan AST pada serum.

Penelitian ini menemukan bahwa terdapat perbedaan yang signifikan pada kadar ALT dan AST serum pada kelompok kontrol positif dengan kelompok perlakuan pada semua dosis pemberian ekstrak daun kemangi. Dimana kadar ALT dan AST serum pada kelompok perlakuan jauh lebih rendah dibandingkan kelompok kontrol positif. Hal ini mengindikasikan bahwa terjadi perbaikan pada status fungsional hepar oleh pemberian ekstrak kemangi ditandai dengan penurunan kadar ALT dan AST serum. Hasil ini sesuai dengan penelitian yang dilakukan oleh Meera et al. (2012) yang membuktikan bahwa pemberian ekstrak kemangi sayur (O.basilicum) secara signifikan mencegah peningkatan marker penanda kerusakan hepar yang ditandai dengan penurunan kadar enzim serum ALT, AST, ALP, dan GGT pada kelompok subjek yang diinduksi oleh $\mathrm{H} 2 \mathrm{O} 2$ dan CCL4. Sejalan dengan penemuan ini, Yacout et al. (2012) pada studinya juga menemukan adanya fungsi protektif yang diberikan ektrak kemangi (O.basilicum) pada kelompok perlakuan yang ditandai dengan adanya penurunan aktivitas serum transaminase (ALT dan AST) yang signifikan dibandingkan pada kelompok subjek yang diberi CCL4 ${ }^{22}$.

Studi yang dilakukan oleh Surana dan Jain (2010) menyebutkan bahwa ekstrak etanol dari spesies Ocimum dapat menurunkan elevasi level enzim ALT dan AST dan menunjukkan proteksi pada integritas struktural membran sel hepatosit dan regenerasi pada sel hepar yang mengalami kerusakan. Begitu juga dengan studi yang dilakukan Mahboun dan Arisha (2015) yang menemukan bahwa pemberian ekstrak $O$. basilicum meningkatkan struktur histologi sel hepar yang rusak akibat induksi dari diazinon serta menunjukkan efek peningkatan fungsi hepar.

Temuan ini menunjukkan keefektifan ekstrak kemangi dalam mencegah kerusakan hepar yang ditandai dengan penurunan kadar ALT dan AST serum pada subjek penelitian. Hal ini mungkin disebabkan adanya senyawa- senyawa dengan aktivitas antioksidan tinggi yang dapat mencegah aktivitas stress oksidatif pada sel hepar. O. basilicum diketahui merupakan sumber flavonoid, yang telah terbukti memiliki berbagai sifat biologis yang terkait mekanisme antioksidan. Sakr et al. (2011) menyimpulkan bahwa efek hepatoprotektif $O$. 
basilicum mungkin terjadi dikaitkan dengan adanya aktivitas antioksidan flavonoidnya. Antioksidan merupakan substansi yang dapat mencegah proses oksidasi pada sel akibat toksin maupun radikal bebas.

Spesies Ocimum mengandung sejumlah besar antioksidan, vitamin $\mathrm{C}$, vitamin $\mathrm{E}$, flavonoid, dan karotenoid. adanya senyawa aktif tersebut memberikan perlindungan terhadap radikal bebas yang diinduksi oleh kerusakan oksidatif komponen seluler yang melibatkan pembentukan molekul ROS. O. Basilicum merupakan salah satu spesies Ocimum yang memiliki aktivitas antioksidan terbesar dibandingkan spesies Ocimum lainnya ${ }^{21}$. Selain kandungan flavonoid, O. basilicum juga mengandung rosmaniric acid yang memiliki efek hepatoprotektif. Penelitian yang dilakukan oleh Mahmood dan Sidik (2005) menyebutkan bahwa O. basilicum memiliki efek hepatoprotektif dan antifibrotik yang dikaitkan dengan aktivitas antioksidan dari rosmaniric acid. Rosmaniric acid menurunkan konversi dari sel stellate hepar menjadi myofibroblast dan menurunkan ekspresi gen komponen matriks ekstraseluler yang dibutuhkan dalam pembentukan fibrosis.

Studi ini menunjukkan efek protektif dari ekstrak daun kemangi (O.basilicum) pada hepar yang diinduksi oleh asam urat. Berbagai mekanisme hepatoproteksi dapat dikaitkan dengan adanya senyawa fitofarmaka pada tanaman ini. Namun, dibutuhkan penyelidikan lebih lanjut untuk mengisolasi dan mengidentifikasi senyawa spesifik yang memiliki sifat hepatoprotektif dari $O$. basilicum sehingga dapat digunakan sebagai terapi pengobatan dalam mencegah kerusakan hepar akibat induksi asam urat.

Penelitian ini masih memiliki keterbatasan yaitu ketidak sesuaian jadwal penelitian dari ketentuan yang telah ditetapkan, karena peneliti kesulitan dalam memperoleh kristal asam urat. Dalam penelitian ini juga tidak dilakukan pemeriksaan kadar ALT dan AST pra- penelitian, dan tidak dilakukan pemeriksaan biomarker lain terhadap fungsi hepar.

\section{KESIMPULAN}

Dari hasil penelitian ini dapat disimpulkan bahwa ekstrak etanol daun kemangi memiliki pengaruh yang bermakna terhadap penurunan kadar ALT dan AST serum mencit yang diinjeksi asam urat.

\section{UCAPAN TERIMAKASIH}

Saya ucapkan terimakasih kepada Fakultas Kedokteran Universitass Muhammadiyah Purwokerto yang telah mendukung pembuatan artikel ini dan menyediakan fasilitas Laboratrium sampai penelitian ini selesai. Kepada petugas laboran laboratorium FK UMP yang berkenan melakukan pengukuran kadar ALT dan AST serum secara objektif. 


\section{DAFTAR PUSTAKA}

1. KEMENKES, RI. (2011) Pedoman Interpretasi Data Klinik. Kementrian Kesehatan Republik Indonesia. 52-56.

2. Soetoko, AS., Arfian, N. \& Romi, MM. (2015) Pengaruh Induksi Asam Urat dan Pemberian Allopurinol Pada Mencit Terhadap Fibrosis Hepar dan Jumlah Sel Stellata Hepar. [Tesis]. Universitas Gajah Mada.

3. Adhika, OA. (2009) Fibrosis Hati. JKM.8 pp.198-211.

4. Kambay, G. (2011) Hubungan Hiperurisemia dan Fraction Uric Acid Clearance. jurnal penyakit dalam. 12, 77-80.

5. Khosla, UM., Zharikov, S., Finch, JL., Nakagawa, T., Roncal, C., Mu, W. et al. (2005) Hyperuricemia induces endothelial dysfunction. Kidney International, Vol. 67.

, pp. 1739-1742.

6. Tasminatum, SS. \& Ningtyas, PM. (2016) Erasan Daun dan Kulit Buah Melinjo (Gnetum gnemon) Sebagai Inducer Asam Urat pada Tikus Putih (Rattus norvegicus). [Penelitian Kemitraan]. Universitas Muhammadiyah Yogyakarta.

7. Sherwood, L. (2014) Fisiologi Manusia.

$6^{\text {th }}$ Edition. Jakarta, EGC.

8. Wynn, TA. (2008) Cellular and molecular mechanisms of fibrosis. J Pathol.

9. Katzung, BG., Masters, SB. \& Trevor, AJ. (2014) Farmakologi Dasar dan Klinik. $12^{\text {th }}$ Edition. Jakarta, EGC.

10. Badan POM RI. (2008) Informatorium Obat Nasional Indonesia. Jakarta, Badan Pengawas Obat dan Makanan Republik Indonesia, Sagung Seto.

11. Turrokhmah, I. (2015) Pengaruh Pemberian Ekstrak Daun Kersen (Muntingia Calabura L.) Dosis Bertingkat Terhadap Gambaran Histopatologi Ginjal Mencit Balb/C yang Hiperurisemia. Karya Tulis Ilmiah, Program Pendidikan Sarjaa Kedokteran, Fakultas Kedokteran, Universitas Diponegoro. Jurnal Kedokteran Diponegoro (JKD), Vol. 5

No.3.

12. Anggun. Ismanto, AY. \& Masi, G. (2016) Pengaruh Air Rebusan Daun Kemangi Terhadap
Kadar Asam Urat Darah Pada Penderita Hiperurisemia di Wilayah Kerja Puskesmas Wolaang. eJurnal Keperawatan (eKp). 4.

13. Mahboub, FA., \& Arisha, SM (2015). Hepatoprotective effect of Ocimum basilicum extract against the toxicity of diazinon in albino rats: histopathologican and immunohistochemical evaluation. World Journal of Pharmaceutical Sciences.

14. Afzali, A. et al., (2010). Association Between Serum Uric Acid Level and Chronic. , pp.578589.

15. Lanaspa, MA. et al., (2012). Uric Acid Stimulates Fructokinase and Accelerates Fructose Metabolism in the Development of Fatty Liver. , $7(10)$.

16. Meera, R. et al., (2009). Antioxidant and hepatoprotective activities of Ocimum basilicum Linn and Trigonella foenumgraecum Linn against $\mathrm{H} \quad 2 \quad \mathrm{O} 2$ and CCI 4 induced hepatotoxicity in goat liver 47 (july), pp. 584-590

17. Sautin, YY. et al., (2007). Adverse effects of the classic antioxidant uric acid in adipocytes: NADPH oxidase-mediated oxidative / nitrosative stress., 224, pp.584-596.

18. Mahmood, SAA., \& Sidik, K. (2005). Synergistic effects of alcoholic extract of sweet basil (ocimum basilicum L.) leaves and honey on cutaneous wound healing in rats. International Journal of Molecular Medicine and Advance Sciences.

19. Surana, J. \& Jain, D. (2010). Protective effect of ocimum gratissimum against carbon tetrachloride induced hepatic damage in rats. Pharmacologyonline.

20. Sakr, SA., El-Abd, SF., Osman, M., Kandil, AM., \& Helmy, MS. (2011). Ameliorative effect of aqueous leave extract of ocimum basilicum on CCL4 - induced hepatotoxicity and apoptosis in albino rats. Journal of American Sciences.

21. Pandey, AK., Singh, P. \& Tripathi, NN. (2014). Chemistry and bioactivities of essential oils of some Ocimum species: an overview. Asian Pacific Journal of Tropical Biomedicine, 4(9), pp.682-694.

22. Yacout, GA., Elguindy, NM. \& Azab, EFEl. (2012). Hepatoprotective effect of basil ( Ocimum basilicum $\mathrm{L}$.) on $\mathrm{CCl} 4$ - induced liver fibrosis in rats. , 11(90), pp.15702-15711. 